\title{
EFFECT OF SHORT- AND LONG-LASTING CHILLING ON PRE-rRNA SYNTHESIS AND TRANSPORT IN ROOT MERISTEMATIC CELLS OF THREE SOYBEAN CULTIVARS
}

\author{
DARIUSZ STĘPIŃSKI \\ Department of Cytophysiology, University of Łódź \\ Pilarskiego 14, 90-231 Łódź, Poland \\ e-mail: dareks@biol.uni.lodz.pl
}

(Received: March 14, 2003. Accepted: July 18, 2003)

\begin{abstract}
Autoradiographic studies of ${ }^{3} \mathrm{H}$-uridine incorporation (20-min incubation) and dynamics of radioactive particle translocation from nucleolus into cytoplasm (following 80-min postincubation in non-radioactive medium) in root meristematic cells of soybean have been carried out. The experiment was performed with plants subjected to 4-day acclimation in chilling or subjected to 2-hour cold stress and control plants. Three cultivars of soybean: Mazowia, Polan and Progres (cultivated in Poland) were used in the experiment.

It has been shown that in control conditions the greatest number of RNA precursor is incorporated into nucleoli after 20-min incubation. Following 80-min postincubation cytoplasm is the most radioactive area of the cell this mainly testifies to dynamic translocation of radioactive ribosome subunits from nucleolus into cytoplasm.

In chilling conditions the reduction of ${ }^{3} \mathrm{H}$-uridine incorporation into cells occurs, as compared to control conditions. Plants subjected to a 4-day acclimation incorporate the radioactive precursor more intensively than plants subjected to cold stress.

Following 80-min postincubation - in the case of acclimated plants - the nucleolus is the most radioactive area of the cell, which testifies to accumulation of pre-rRNA in it. After the cold stress cytoplasm is more radioactive than the nucleolus. In all three cultivars the processes of synthesis and transport of pre-rRNA particles are similar, only their intensity is different.

Morphometric measurements of nucleoli in all cultivars subjected to 4-day chilling have shown that root cell nucleoli are larger than those in control. This phenomenon can be connected with stronger inhibition of rRNA transport than its synthesis.
\end{abstract}

KEY WORDS: acclimation, chilling, ${ }^{3} \mathrm{H}$-uridine incorporation, nucleolus, soybean.

\section{INTRODUCTION}

Low temperature stress is one of the major problems in agricultural production. It mainly refers to chill-sensitive plants, including soybean plants, which poorly tolerate exposure to temperatures between $15-0^{\circ} \mathrm{C}$ (Chen 1994). Chilling stress causes a number of changes at cytophysiological level leading to weakening and/or impairment of some cellular processes, thus it leads to reduction of plant development and growth (Mc Kersie and Leshem 1994). Disturbances of cell physiology can occur at different stages of cellular processes including the stage of machinery production for protein synthesis, which takes place in the nucleolus.

Nucleolus, though it is a plurifunctional cellular structure (Pederson 1998), is primarily the site of pre-rRNA synthesis and of maturation of pre-ribosomal subunits (Olson et al. 2000; Visintin and Amon 2000; Ospina and Matera
2002). Nucleolus is one of the least stable cellular organelles. Its activity, morphology and ultrastructure change alongside with species, cell type, grade of cell differentiation and cell cycle (Kwiatkowska and Maszewski 1985; Guerrero et al. 1989). The nucleolus reflects the functional state of the cell, reacting quickly to physiological and pathological factors (Goessens 1984; Scheer and Hock 1999; Olson et al. 2000). It is the structure responsive to abiotic stress factors including low temperature (Gabara 1980; Stępiński and Kwiatkowska 2003) and heavy metals (Gabara et al. 1995; Jiang et al. 2000). It is thought that nucleolar sizes are the indicator of metabolic activity of the cells. Usually, the bigger the nucleoli, the higher the activity characterizes the cell (Martini et al. 1982; Fischer et al. 1991). Nucleolar sizes depend, in the majority of cases, on the number of active rRNA genes (Flavell and O'Dell 1979). However, the relation between dynamics of rRNA synthesis and rRNA migration to cytoplasm also influen- 
ces dimensions of nucleoli. Increase in nucleolar volume was observed in meristematic root cells of soybean seedlings cv. Aldana subjected to chilling $\left(10^{\circ} \mathrm{C}\right)$. Simultaneously, cold drastically decreased the activity of rRNA synthesis. Enlargement of nucleoli was caused by pre-rRNA accumulation in them, owing to stronger inhibition of rRNA transport to cytoplasm than dynamics of its synthesis (Stępiński and Kwiatkowska 2003).

The aim of the present work was to verify, whether processes of synthesis and transport of pre-rRNA, observed in soybean cv. Aldana, proceed similarly also in other cultivars of soybean in the following conditions: 1) 4-day chill $\left(10^{\circ} \mathrm{C}\right)$, during which some mechanisms and cellular pathways can adjust to changed physiological situation, and 2) at the beginning of low temperature treatment ( 2 hours), during which plants suffer from cold shock. Morphometric measurements of nucleolar volumes were also performed.

The above mentioned experiments were carried out on root meristematic cells of three cultivars of Glycine max. cultivated in Poland. Differences in intensity of the processes examined at lowered temperature at particular cultivars could indicate the degree of their susceptibility to chill.

Soybean is an attractive plant to study nucleolus because in its meristematic interphase cell there is a single nucleolus. Nucleolus organizer region (NOR) is localized only on chromosome 13 (Griffor et al. 1991).

\section{MATERIAL AND METHODS}

Seeds of soybean (Glycine $\max$ (L.) Merr.) of three cultivars: Mazowia, Polan and Progres (obtained from IHAR in Radzików) were germinated for 3 days at $25^{\circ} \mathrm{C}$ (control) in darkness in Petri dishes on filter paper wetted with distilled water. Then seedlings were transferred to cold $\left(10^{\circ} \mathrm{C}\right)$ for 4 days (acclimation) or for 2 hours (cold stress).

\section{Incubation in ${ }^{3} \mathrm{H}$-uridine}

Seedling roots of each cultivar were incubated in water containing ${ }^{3} \mathrm{H}$-uridine $(3.7 \mathrm{MBq} / \mathrm{ml} ; 888 \mathrm{GBq} / \mathrm{mM})$ for 20 min at $25^{\circ} \mathrm{C}$ (control) or at $10^{\circ} \mathrm{C}$ (both acclimated and subjected to cold stress). Half of the seedlings from each group was postincubated for $80 \mathrm{~min}$ in non-radioactive medium at $25^{\circ} \mathrm{C}$ or $10^{\circ} \mathrm{C}$ respectively. Roots were fixed in absolute ethanol - glacial acetic acid mixture (3:1) (v/v) for 1 $\mathrm{h}$ at room temperature, washed with ethanol and kept in $70 \%$ ethanol for further procedure. The material was then treated with pectinase solution at $45^{\circ} \mathrm{C}$ for $30 \mathrm{~min}$ and rinsed in Mc Ilvain buffer ( $\mathrm{pH}$ 5.0). Meristematic parts of roots were placed on microscope slides in a water drop and squashed. After freezing on dry ice and removing coverslips the slides were dried, covered with photosensitive emulsion and exposed in darkness at $8^{\circ} \mathrm{C}$. Following 14 days the autoradiograms were developed and stained with tolui-

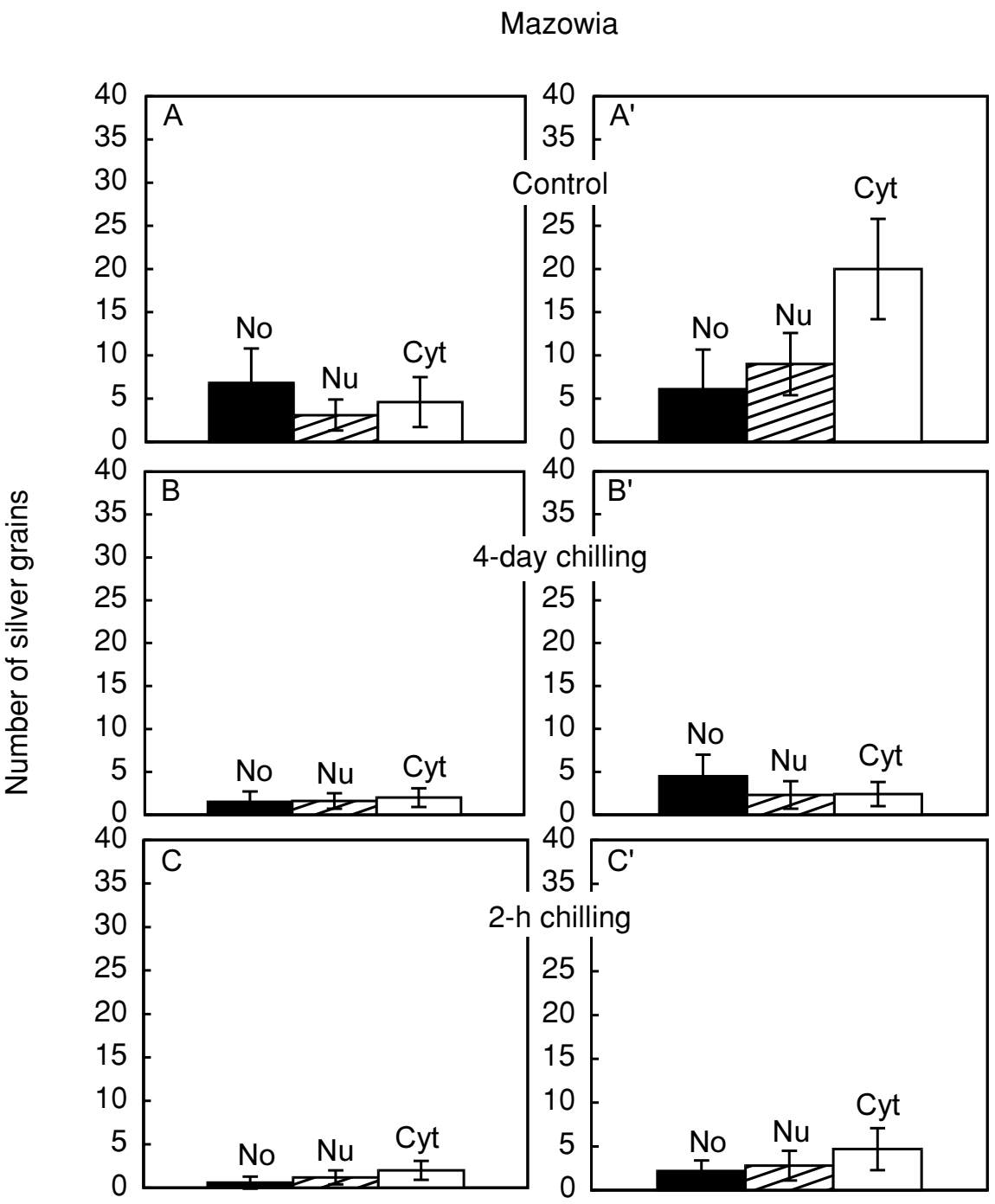

Fig. 1. Mean number of silver grains above nucleolus (No), extra-nucleolar nucleoplasm $(\mathrm{Nu})$ and cytoplasm $(\mathrm{Cyt})$ of root meristematic cells of soybean cv. Mazowia. A - control $\left(25^{\circ} \mathrm{C}\right)$, after 20 -min incubation in ${ }^{3} \mathrm{H}$-uridine; A' - control, after 80-min postincubation in non-radioactive medium; B - 4-day acclimation at $10^{\circ} \mathrm{C}$, after 20 -min incubation in ${ }^{3} \mathrm{H}$-uridine; B' - 4-day acclimation at $10^{\circ} \mathrm{C}$, 80-min postincubation; $\mathrm{C}-2$-hour cold shock at $10^{\circ} \mathrm{C}$, after 20 -min incubation in ${ }^{3} \mathrm{H}$-uridine; C' -2 -hour cold shock at $10^{\circ} \mathrm{C}$, 80-min postincubation. Bars represent standard errors. 
dine blue according to Smetana's method (Smetana et al. 1968) and embedded in Canadian balsam.

Silver grains were counted over nucleoli, extra-nucleolar nucleoplasm and cytoplasm in 30 cells in preparations from 3 meristems from each variant.

\section{Morphometric analysis of nucleoli}

Nucleolar morphometric measurements were carried out on squashed slides made of apical parts of roots fixed in 0.0125 M Sörensen's phosphate buffer ( $\mathrm{pH}$ 7.2) with $2 \%$ glutaraldehyde and stained using Ag-NOR impregnation method described by Howell and Black (1980). An assumption has been made that nucleoli did not get flattened during squashed slide preparation and that nucleolar profiles are circle-shaped. Their areas were measured with the computer-aided IMAL-512 system. After the radiuses of nucleoli had been established the nucleolar volumes were calculated employing mathematical formula. Volume measurements were performed for 90 nucleoli for each variant.

\section{RESULTS}

\section{${ }^{3} \mathrm{H}$-uridine autoradiography}

In control conditions $\left(25^{\circ} \mathrm{C}\right)$ nucleoli are the most labelled area following 20-min incubation of roots in ${ }^{3} \mathrm{H}$-uridine in all cultivars. Cytoplasm is about $50 \%$ weaker labelled than nucleoli. The isotope is most intensively incorporated into nucleoli in cv. Progres, and least - in cv. Mazowia. Extranucleolar nucleoplasm is the least radioactive area in all cultivars of soybean (Fig. 1A, 2A, 3A). Following 80-min postincubation of roots in non-radioactive medium at $25^{\circ} \mathrm{C}$ cytoplasm becomes the most radioactive area of the cell in all cultivars. It is on average about 3-fold more labelled than nucleoli. Whereas nucleoli are the least radioactive area. This testifies to dynamic transport of radioactive particles from nucleolus to cytoplasm. The greatest number of silver grains over cytoplasm is observed in cv. Progres, the smallest - in cv. Mazowia (Fig. 1A', 2A', 3A').

Under chilling conditions, both 4-day and 2-hour, the considerable reduction of radioactive uridine incorporation into cells during 20-min incubation and also of translocation of labelled particles from nucleolus to cytoplasm during 80-min postincubation occur. Comparing the number of silver grains, after $20 \mathrm{~min}$ incubation in ${ }^{3} \mathrm{H}$-uridine, over nucleoli of control plants and those subjected to 4-day chilling, it has been stated that the strongest reduction of isotope incorporation into nucleoli occurs in cv. Mazowia (5-fold); to a lesser degree - in cultivars: Polan (4-fold), Progres (3-fold) (Fig. 1A, 1B; 2A, 2B; 3A, 3B). After 80-min postincubation in non-radioactive medium the nucleoli are labelled stronger than cytoplasm - contrary to the case of

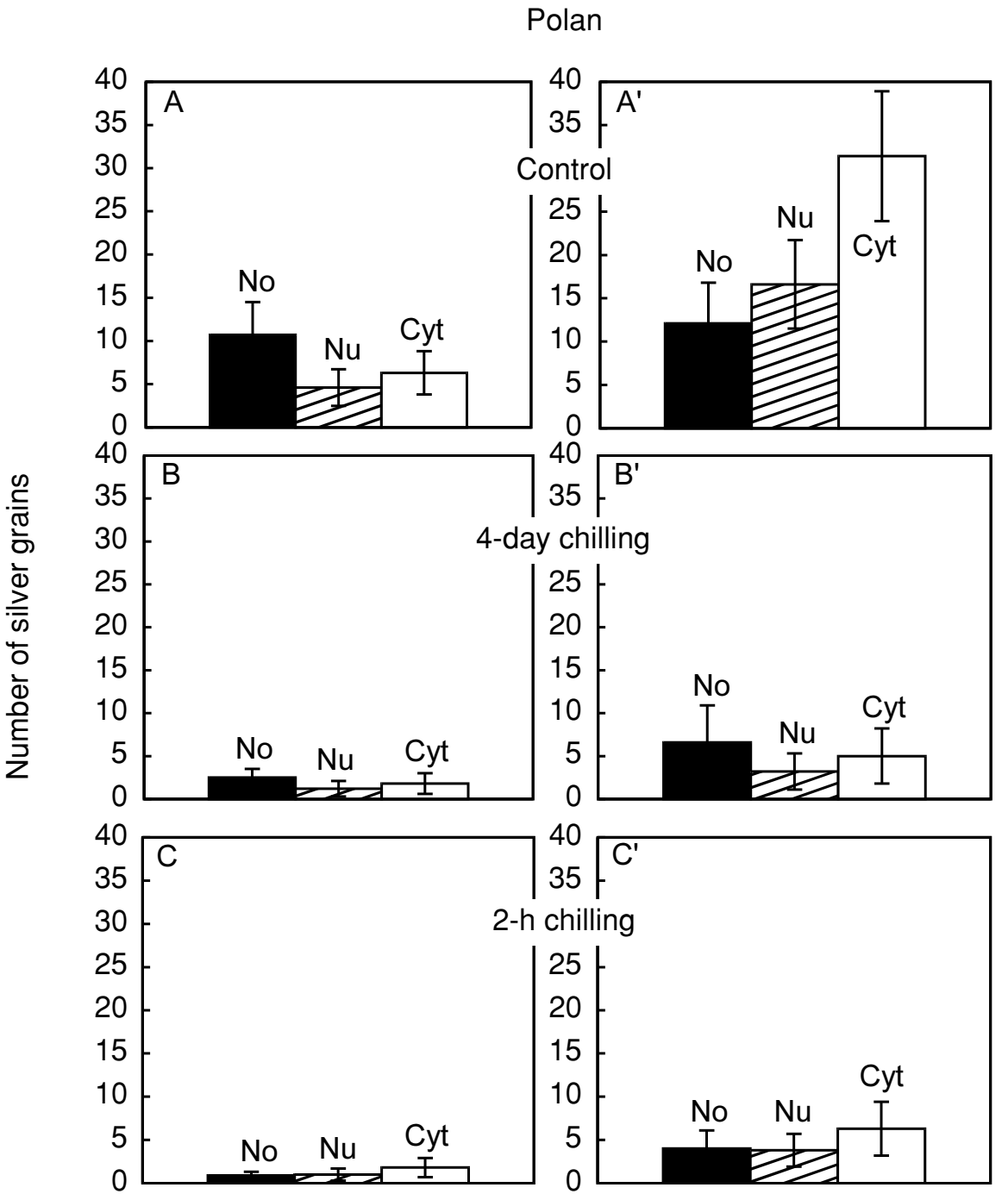

Fig. 2. Mean number of silver grains above nucleolus (No), extra-nucleolar nucleoplasm $\mathrm{Nu})$ and cytoplasm $(\mathrm{Cyt})$ of root meristematic cells of soybean cv. Polan. A - control $\left(25^{\circ} \mathrm{C}\right)$, after 20 -min incubation in ${ }^{3} \mathrm{H}$-uridine; A' - control, after 80-min postincubation in non-radioactive medium; B - 4-day acclimation at $10^{\circ} \mathrm{C}$, after 20 -min incubation in ${ }^{3} \mathrm{H}$-uridine; B' - 4-day acclimation at $10^{\circ} \mathrm{C}$, 80-min postincubation; $\mathrm{C}-2$-hour cold shock at $10^{\circ} \mathrm{C}$, after 20 -min incubation in ${ }^{3} \mathrm{H}$-uridine; C' -2 -hour cold shock at $10^{\circ} \mathrm{C}$, 80-min postincubation. Bars represent standard errors. 
control plants - in all cultivars. The most strongly labelled nucleoli were observed in cv. Progres, and the least - in cv. Mazowia (Fig. 1B', 2B', 3B'). Comparing the labelling intensity of control plant cell cytoplasm and those subjected to chilling following postincubation, one can draw a conclusion about the effect of low temperature on dynamics of transport of matured pre-ribosomal particles from nucleolus to cytoplasm. The strongest inhibition of radioactive particle translocation takes place in cv. Mazowia (8-fold), then in cultivars: Polan (6-fold) and Progres (5-fold) (Fig. 1A', 1B'; 2A', 2B'; 3A', 3B').

In the case of plants subjected to short-lasting chill (cold stress) the reduction of ${ }^{3} \mathrm{H}$-uridine incorporation after 20 min incubation is even stronger than in acclimated plants (Fig. 1C, 2C, 3C). Following 2-hour chilling of seedlings, the most reduced isotope incorporation into nucleoli is observed in cv. Polan (12-fold), less - in cultivars Progres and Mazowia (10-fold) (Fig. 1C, 2C, 3C). After postincubation the labelling of particular cellular areas increases in comparison with labelling immediately following incubation. However, in this case, more intensive radioactivity of cytoplasm than nucleoli is observed - contrary to acclimated plants (Fig. 1C', 2C', 3C').

Following postincubation time an increase in radioactivity of whole cells in all variants is observed. This testifies to further incorporation of isotope, which entered into roots during incubation time.

\section{Nucleolar size}

The mean volumes of nucleoli in root meristematic cell of seedlings grown at optimal conditions $\left(25^{\circ} \mathrm{C}\right)$ range from 12 $\mu^{3}$ in cv. Progres to $21 \mu^{3}$ in cv. Polan (Fig. 4). After 4-day acclimation of seedlings at $10^{\circ} \mathrm{C}$ the nucleoli enlarge considerably in all cultivars in comparison with control. Nucleolar volume in cv. Polan increases by about $77 \%$, in Mazowia about $172 \%$, and in Progres about $210 \%$ (Fig. 4). Nucleoli of plants treated with short-lasting chill (2-h) also become bigger than in the control (the difference is statistically significant), but not so drastically as in acclimated seedlings. Nucleolar volume increases most in cv. Mazowia about $74 \%$ and least in cv. Polan - about $21 \%$ (Fig. 4).

\section{DISCUSSION}

Soybean is a plant susceptible to chill, originating from subtropical climatic zone. The optimal temperature for soybean growth, development and symbiotic activity is about $25-30^{\circ} \mathrm{C}$ (cited after Zhang et al. 1995). Temperature of $10^{\circ} \mathrm{C}$ is the lowest allowing vegetation of some cultivars of soybean (c.a. Jasińska and Kotecki 1993). Therefore, in the present studies the temperature of $10^{\circ} \mathrm{C}$ has been applied as a factor eliciting chilling stress. Therefore, the fact is not surprising that some cellular processes, including those in nucleoli, have been handicapped.

\section{Progres}

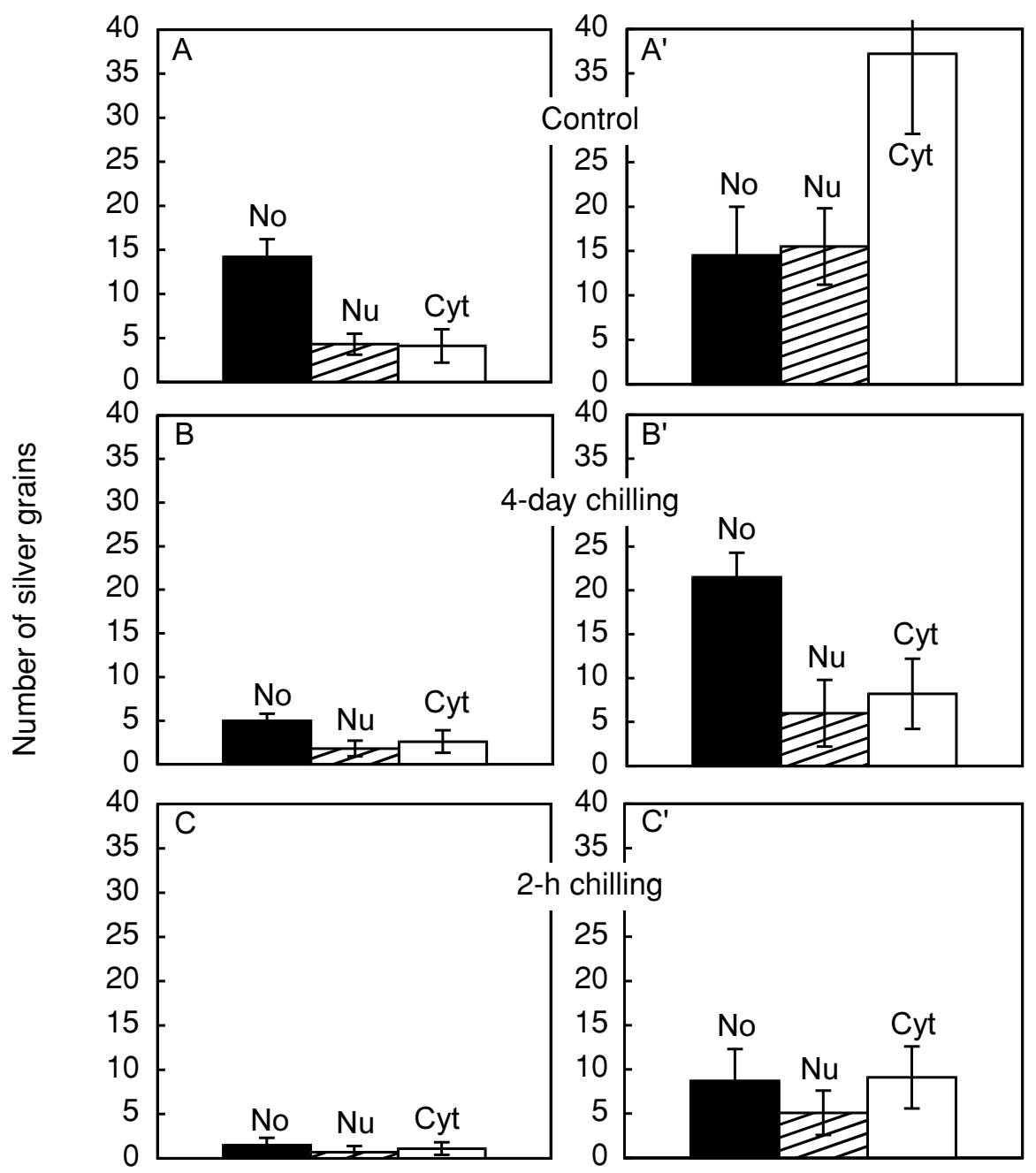

Fig. 3. Mean number of silver grains above nucleolus (No), extra-nucleolar nucleoplasm $\mathrm{Nu}$ ) and cytoplasm (Cyt) of root meristematic cells of soybean cv. Progres. A - control $\left(25^{\circ} \mathrm{C}\right)$, after 20 -min incubation in ${ }^{3} \mathrm{H}$-uridine; A' - control, after 80-min postincubation in non-radioactive medium; B - 4-day acclimation at $10^{\circ} \mathrm{C}$, after 20 -min incubation in ${ }^{3} \mathrm{H}$-uridine; B' - 4-day acclimation at $10^{\circ} \mathrm{C}$, 80-min postincubation; $\mathrm{C}-2$-hour cold shock at $10^{\circ} \mathrm{C}$, after 20 -min incubation in ${ }^{3} \mathrm{H}$-uridine; C' -2 -hour cold shock at $10^{\circ} \mathrm{C}$, 80-min postincubation. Bars represent standard errors. 


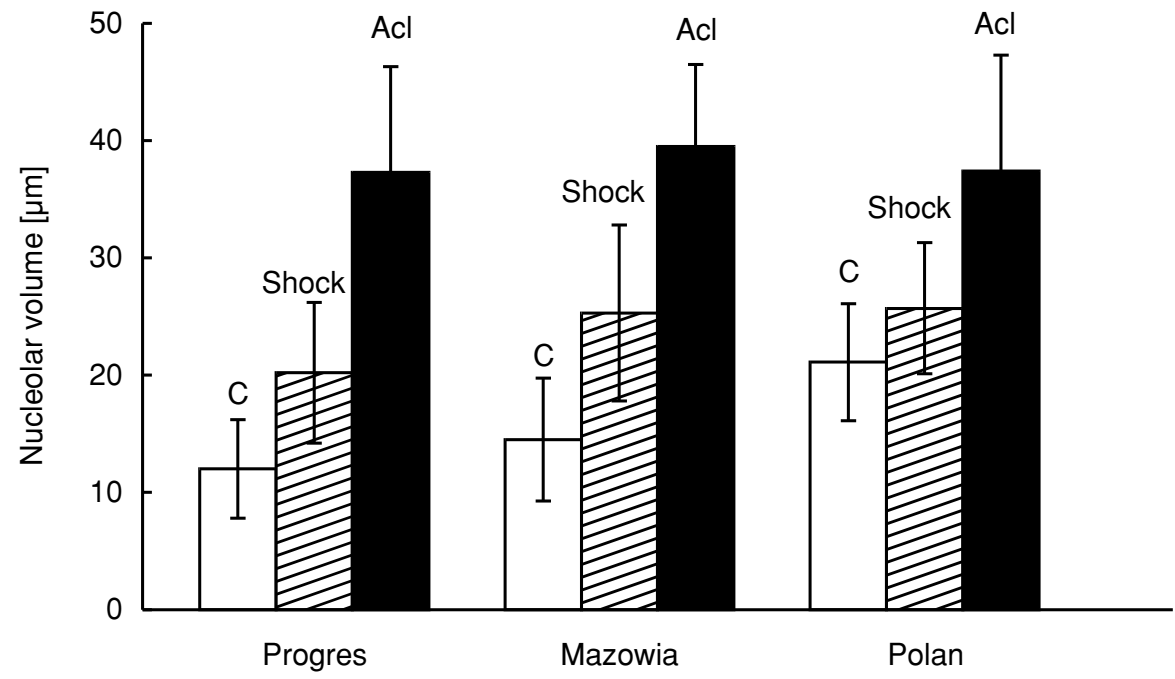

Fig. 4. Mean volumes of nucleoli in root meristematic cells of soybean of three cultivars: Progres, Mazowia and Polan. C - control $\left(25^{\circ} \mathrm{C}\right)$; Shock - 2-hour cold shock at $10^{\circ} \mathrm{C}$; $\mathrm{Acl}-4$-day acclimation at $10^{\circ} \mathrm{C}$. Bars represent standard errors.
A contribution of nucleus in transcription in plants is 80\% (Giménez-Martin et al. 1977) - hence, in the present work only the synthesis and transport of ribosomal RNA have been considered.

Results of the present studies, performed with some cultivars of soybean, confirmed the results of experiments which had been carried out previously on Glycine max. cv. Aldana (Stępiński and Kwiatkowska 2003) and also on other species: Helianthus annuus, Secale cereale, Vicia faba, and Allium cepa (Olszewska et al. 1987; Olszewska et al. 1988), which showed that synthesis, maturation and transport of pre-ribosomal particles in root meristematic cells had been slowed down by low temperature (including $10^{\circ} \mathrm{C}$ ) to a considerable extent. However, the data, shown in the present paper and the previous publication (Stępiński and Kwiatkowska 2003), indicate that transport of pre-ribosomal particles is more reduced than their synthesis following 4-day chill treatment. This phenomenon is observed in all soybean cultivars examined: Aldana (Stępiński and Kwiatkowska 2003) as well in Mazowia, Polan and Progres (present paper).

Nucleolar size depends mostly on dynamics of 1) pre-rRNA synthesis and 2) its maturation and transport to cytoplasm. Morphometric measurements show that in all cultivars examined, similarly as in cv. Aldana (Stępiński and Kwiatkowska 2003) in chill-treated soybean seedlings the nucleoli become bigger. This phenomenon may be caused by the fact mentioned above, i.e. that low temperature inhibits rRNA synthesis to a smaller extent than ribosome subunits maturation and transport from nucleolus to cytoplasm. This happens, at least, in the case of plants subjected to long-lasting chilling. A hypothesis has been put forward that the arrest of pre-ribosomes in a nucleolus may protect them against a destructive ribonuclease effect as its activity increases in chill-treated seedlings (Stępiński 2002). During regeneration at optimal temperature $\left(25^{\circ} \mathrm{C}\right)$ high activity of synthesis and transport of ribosome subunits into cytoplasm is restored (Stępiński, unpublished data), while ribonuclease activity drastically decreases (Stępiński 2002).

An insignificant - in comparison with nucleoli of acclimated plants - increase in nucleolar size is also observed in plants subjected to short-lasting chilling. Enlargement of nucleoli appeared in spite of more intensive dynamics of transport of pre-rRNA than its synthesis. No accumulation of radioactive particle in nucleolus was observed - this is proved by higher labelling of cytoplasm than nucleoli following postincubation time. Ultrastructural studies performed previously show notable loosening of nucleolar structure in root meristematic cells of soybean seedlings grown under 4-day chill (Stępiński and Kwiatkowska 2003). One may suppose that insignificant enlargement of nucleoli in short-chilled plants results from the change of their structure. In the case of long-chilled plants both processes, i.e. the loosening of structure and the accumulation of pre-rRNA particles add up, resulting in about 2-fold increase in nucleolar volume.

Intensity of the examined processes differ to some extent, both under control conditions and at $10^{\circ} \mathrm{C}$. The intensity of ${ }^{3} \mathrm{H}$-uridine incorporation and labelling migration to cytoplasm in optimal conditions for soybean development and growth can testify to differences in vitality of seedlings, whereas under unfavourable chill - to different capability of adjusting to the new situation.

On the basis of the results obtained it seems that in $\mathrm{cv}$. Polan both pre-rRNA synthesis in nucleolus and pre-ribosome transport to cytoplasm are the most susceptible processes at the beginning of chilling stress. Mazowia and Progres cultivars react alike and both are less sensitive than cv. Polan. Whereas, following 4-day acclimation time in chill both processes adjusted best in cv. Progres, and worst - in cv. Mazowia.

\section{ACKNOWLEDGMENTS}

I am grateful to Prof. Maria Kwiatkowska for her valuable advice and comments during the experimental part and preparation of the manuscript.

\section{LITERATURE CITED}

CHEN T.H.H. 1994. Plant adaptation to low temperature stress. Can. J. Plant Pathol. 16: 231-236.

FISCHER D., WEISENBERGER D., SCHEER U. 1991. Assigning functions to nucleolar structures. Chromosoma 101: 133-140. 
FLAVELL R.B., O’DELL M. 1979. The genetic control of nucleolus formation in wheat. Chromosoma 71: 135-152.

GABARA B. 1980. Effect of low temperature on the nucleolus of larkspur (Delphinium ajacis L.) meiocytes. Folia Histochem. Cytochem. 18: 259-266.

GABARA B., KRAJEWSKA M., STECKA E. 1995. Calcium effect on number, dimension and activity of nucleoli in cortex cells of pea (Pisum sativum L.) roots after treatment with heavy metals. Plant Sci. 111: 153-161.

GIMENEZ-MARTIN G., DE LA TORRE C., LÓPEZ-SÁEZ J., ESPONDA P. 1977. Plant nucleolus: structure and physiology. Cytobiol. 14: 421-462.

GOESSENS G. 1984. Nucleolar structure. Int. Rev. Cytol. 87: 107-158.

GRIFFOR M.C., VODKIN L.O., SINGH R.J., HYMOWITZ T. 1991. Fluorescent in situ hybridization to soybean metaphase chromosomes. Plant Mol. Biol. 17: 101-109.

GUERRERO F., DE LA TORRE C., GARCIA-HERDUGO G. 1989. Control of nucleolar growth during interphase in higher plant meristem cells. Protoplasma 152: 96-100.

HOWELL W.M., BLACK D.A. 1980. Controlled silver-staining of nucleolus organizer regions with a protective colloidal developer: a 1-step method. Experientia 36: 1014.

JASIŃSKA Z., KOTECKI A. 1993. Soja. In: Rośliny strączkowe. Skupińska M. (ed.). PWN, Warszawa, pp. 146-167. (in Polish)

JIANG W., LIU D., LI H. 2000. Effects of $\mathrm{Cu}^{2+}$ on root growth, cell division, and nucleolus of Helianthus annuиs L. Sci Total Environ. 256: 59-65.

KWIATKOWSKA M., MASZEWSKI J. 1985. Functional and structural heterogeneity of nucleoli: the dependence of the activity of transport of newly synthesised rRNA on nucleolar size and phase of the cell cycle. Folia Histochem. Cytobiol. 23: 117-126.

MARTINI G., O'DELL M., FLAVELL R.B. 1982. Partial inactivation of wheat nucleolus organizers by the nucleolus organizer chromosomes from Aegilops umbellulata. Chromosoma 84: 697-700.

MC KERSIE B.D., LESHEM Y.Y. 1994. Chilling stress. In: Stress and Stress Coping in Cultivated Plants. Kluwer Academik Publishers, Dordrecht-Boston-London, pp. 79-103.
OLSON M.O.J., DUNDR M., SZEBENI A. 2000. The nucleolus: an old factory with unexpected capabilities. Trends Cell Biol. 10: 189-196.

OLSZEWSKA M.J., KURAN H., DAMSZ B., MARCINIAK K. 1987. Autoradiographic, ultrastructural and interferometric analyses of the temperature effect on the synthesis and migration of ribosomes in root meristem cells of Helianthus annuиs L. Relation to $\mathrm{S}$ phase initiation. Folia Histochem. Cytobiol. 24: 69-78.

OLSZEWSKA M.J., KURAN H., MARCINIAK K. 1988. Relationship between resumption of rRNA transport into cytoplasm after cold treatment and progression through the cell cycle in root meristem cells. Environ. Exp. Bot. 28: 375-380.

OSPINA J.K. MATERA A.G. 2002. The nucleolus weighs in. Current Biol. 12: 29-31.

PEDERSON T. 1998. The plurifunctional nucleolus. Nucleic Acids Res. 26: 3871-3876.

SCHEER U., HOCK R. 1999. Structure and function of the nucleolus. Curr. Opin. Cell Biol. 11: 385-390.

SMETANA K., LEJNER J., POTMESIL M. 1968. A further contribution to the demonstration of RNA and nucleoli of blood cells in smear preparations. Folia Hematol. 91: 381-393.

STĘPIŃSKI D. 2002. Changes in ribonuclease activity in roots of soybean seedlings subjected to chilling and recovery. Acta Physiol. Plant. 24: 297-301.

STĘPIŃSKI D., KWIATKOWSKA M. 2003. Autoradiographic and ultrastructural studies of the influence of chilling on soybean root meristem nucleoli. Acta Biol. Cracov. Ser. Bot. (in press).

VISINTIN R., AMON A. 2000. The nucleolus: the magician's hat for cell cycle tricks. Curr. Opin. Cell Biol. 12: 372-377 .

ZHANG F., HAMEL C., KIANMEHR H., SMITH D.L. 1995. Root-zone temperature and soybean [Glycine max. (L.) Merr.] vesicular-arbuscular mycorrhizae: development and interactions with the nitrogen fixing symbiosis. Environm. Exp. Bot. 35: 287-298.

\title{
WPŁYW KRÓTKO- I DŁUGOTRWAŁEGO CHŁODU NA SYNTEZE I TRANSPORT PRE-rRNA W KOMÓRKACH MERYSTEMATYCZNYCH KORZENI TRZECH ODMIAN SOI
}

\author{
STRESZCZENIE
}

Przeprowadzono autoradiograficzne badania włączania ${ }^{3} \mathrm{H}$-urydyny (20-minutowa inkubacja) i dynamiki przemieszczania się wyznakowanch cząstek z jąderka do cytoplazmy po 80-minutowej postincubacji w środowisku nieradioaktywnym w komórkach merystematycznych korzeni soi. Eksperyment wykonano na roślinach poddanych 4-dniowej aklimatyzacji w chłodzie, poddanych 2-godzinnemu stresowi chłodu oraz na roślinach kontrolnych. Eksperyment prowadzono na 3 odmianach soi hodowanych w Polsce: Mazowia, Polan i Progres.

Wykazano, że w warunkach kontrolnych po 20 -minutowej inkubacji korzeni w ${ }^{3} \mathrm{H}$-urydynie najwięcej prekursora RNA włącza się do jąderek. Po 80-minutowej postinkubacji najsilniej wyznakowanym obszarem jest cytoplazma, co świadczy głównie o dynamicznym przemieszczaniu się znakowanych podjednostek rybosomów z jąderka do cytoplazmy. W chłodzie następuje znaczne obniżenie włączania ${ }^{3} \mathrm{H}$-urydyny do komórek, w stosunku do warunków kontrolnych. Rośliny poddane 4-dniowej aklimatyzacji intensywniej włączają prekursor radioaktywny, niż rośliny poddane stresowi chłodu. Po 80 minutowej postinkubacji, w przypadku roślin aklimatyzowanych, najsilniej wyznakowanym obszarem komórki jest jąderko, co świadczy o kumulowaniu w nim pre-rRNA. W warunkach stresu chłodu cytoplazma jest bardziej wyznakowana od jąderek. Omawiane procesy syntezy i transportu cząstek pre-rybosomowych, dla wszystkich trzech odmian, przebiegają podobnie, ale z odmienną intensywnością.

Morfometryczne pomiary wielkości jąderek wykazały, że jąderka w komórkach korzeni siewek wszystkich odmian poddanych 4-dniowemu chłodzeniu znacznie zwiększają swą objętość w porównaniu z objętością jąderek kontrolnych. Zjawisko to może mieć związek z silniejszym zahamowaniem transportu rRNA, niż jego syntezy.

SŁOWA KLUCZOWE: aklimatyzacja, chłód, włączanie ${ }^{3} \mathrm{H}$-urydyny, jąderko, soja. 